\title{
POTENSI EKSTRAK DAUN SIRSAK (Annona muricata, L.) SEBAGAI INSEKTISIDA KUTU DAUN PERSIK (Myzus persicae, Sulz) PADA DAUN TANAMAN CABAI RAWIT (Capsicum frutescens)
}

\author{
Feri Hartini ${ }^{1}$ dan Yahdi $^{2}$ \\ ${ }^{1}$ Jurusan Tadris IPA Biologi FITK IAIN Mataram \\ ${ }^{2}$ Dosen Jurusan Tadris IPA Biologi FITK IAIN Mataram
}

\begin{abstract}
Abstrak
Sirsak merupakan tanaman tahunan yang dapat tumbuh dan berbuah sepanjang tahun jika kondisi air tanah terpenuhi selama pertumbuhannya. Di dalam tanaman ini terkandung senyawa acetogenins yang bermanfaat. Senyawa ini tidak hanya terkandung pada buah, tetapi juga hampir seluruh bagian pada tanaman sirsak baik itu daun, batang, akar maupun bijinya. Kandungan acetogenins yang ada pada ekstrak daun sirsak dapat dimanfaatkan sebagai insektisida nabati yang ramah lingkungan. Pada penelitian ini dilakukan uji potensi ekstrak daun sirsak sebagai insektisida kutu daun persik (Myzus persicae, Sulz). Penelitian ini menggunakan penelitian jenis eksperimen kuantitaif dengan menggunakan analisis uji proporsi. Analisis ini digunakan untuk mengetahui seberapa besar potensi ekstrak daun sirsak sebagai insektisida kutu daun persik. Dari hasil penelitian ini diketahui bahwa ekstrak daun sirsak (Annona muricata, L) memiliki potensi sebagai insektisida kutu daun persik. Kekuatan aktivitas ekstrak daun sirsak terhadap kutu daun persik mencapai $100 \%$ pada konsentrasi $8 \%$ dan 10\%. Potensi dari ekstrak daun sirsak sebagai insektisida kutu daun persik termasuk sangat tinggi yaitu $100 \%$.
\end{abstract}

Kata kunci: potensi, ekstrak daun sirsak, kutu daun persik. 


\section{PENDAHHULUAN}

Cabai merupakan salah satu jenis tanaman holtikultura yang banyak diminati konsumen di Indonesia. Tingkat konsumsi cabai cukup tinggi dan cenderung meningkat setiap tahun. Hama dan penyakit merupakan salah satu kendala terbesar dalam usaha budi daya cabai. Menurut Direktorat Perlindungan Tanaman, Ditjen Hortikultura, penurunan produksi dan meroketnya harga cabai pada Januari 2011 terjadi akibat serangan hama dan penyakit. Jenis hama yang banyak menyerang, diantaranya thrips, lalat buah, dan kutu persik (Neni Rostini. 2011).

Salah satu hama penting yang menyerang tanaman cabai ialah kutu daun persik atau disebut dengan bahasa ilmiah Myzus persicae, Sulz. Serangga hama ini ditemukan pada bagian bawah daun. Kutu daun persik menghisap cairan sel sampai daun berwarna kekuningan. Akibatnya pertumbuhan tanaman terhambat, daun berkeriput, layu, kemudian mati. Hama ini juga bertindak sebagai vector penyakit virus. Tak jarang para petani cabai mengeluhkan hal ini. Kerugian akibat keberadaan hama ini ialah pertumbuhan cabai tidak bagus, bahkan gagal panen (Anonim, 2013). Untuk mengatasi masalah tersebut dapat dilakukan pembasmian atau pengusiran. Pembasmian dan pengusiran yang tidak tepat atau tidak ramah lingkungan dapat merusak lingkungan. Oleh karena itu, perlu dilakukan pembasmian atau pengusiran dengan cara yang ramah lingkungan seperti pestisida alami.

Salah satu tanaman yang bisa dijadikan sebagai pestisida nabati yaitu sirsak (Annona muricata, L). Daun dan biji sirsak dapat berperan sebagai insektisida, larvasida, revellent (penolak serangga), dan antifeedant (penghambat makanan) dengan cara kerja sebagai racun kontak dan racun perut. Ekstrak daun sirsak dapat dimanfaatkan untuk menanggulangi hama belalang dan hama-hama lainnya. Kandungan aktif yang terdapat pada sirsak yaitu buah yang mentah, biji, daun dan akarnya mengandung senyawa kimia annonain yang bersifat racun pada serangga (Agus Kardinan. 2002 ). 
Senyawa aktif dari daun A. muricata yaitu tanin dan acetogenin mulai bekerja ketika sampai di usus. Tanin menghambat aktivitas enzim pada saluran pencernaan serangga sedangkan senyawa acetogenin meracuni sel-sel saluran pencernaan akhirnya serangga uji mengalami kematian. Menurut Dadang (1999), tanin merupakan senyawa yang dapat menghambat ketersedian protein dengan membentuk kompleks yang kurang bisa dicerna oleh serangga, sedangkan menurut Mulyaman, dkk (2000), bahwa senyawa acetogenin bersifat sebagai toksin yang dapat meracuni sel-sel lambung (A. Tenrirawe. 2011 ). Adapun maksud dan tujuan dari penelitian ini adalah untuk mengetahui potensi ekstrak daun sirsak (Annona muricata, L.) sebagai insektisida kutu daun persik (Myzus persicae, Sulz) pada daun tanaman cabai rawit (Capsicum frutescens).

\section{METODE}

Penelitian ini menggunakan jenis penelitian eksperimen dengan pendekatan kuantitatif. Dalam penelitian ini terdapat beberapa tahapan antara lain pembuatan ekstrak, pembiakan kutu, dan uji insektisida.

\section{Pembuatan ekstrak}

Daun sirsak (200-250 gram) ditumbuk atau dihaluskan menggunakan blender atau alat penggerus. Kemudian dilakukan maserasi pada serbuk daun sirsak. Penguapan serbuk daun sirsak menggunakan rotary evaporator. Pengenceran ekstrak daun sirsak sesuai dengan konsentrasi yang dibutuhkan yaitu $0 \%, 2 \%, 4 \%$, $6 \%, 8 \%$, dan $10 \%$.

\section{Pembiakan kutu daun persik (Myzus persicae, Sulz)}

Pembiakannya dilakukan dengan melepaskan imago kutu daun persik pada tanaman cabai yang telah ditanam sebelumnya. Membiarkan kutu daun persik selama 20-25 hari sesuai siklus hidupnya untuk memperoleh kutu dengan umur yang sama. 
Mempersiapkan sampel hama kutu daun persik cabai yang sudah dibiakkan. Memberikan label pada masing-masing daun tanaman cabai sesuai dengan perlakuan dan ulangan yang diberikan.

\section{Uji insektisida ekstrak daun sirsak}

Mengamati jumlah kutu daun persik (Myzus persicae, Sulz) pada setiap daun cabai yang telah diberi label dengan bantuan lup atau kaca pembesar. Mencatat jumlah kutu daun pada setiap daun yang telah diberi label sebelum penyemprotan dilakukan. Menyemprotkan ekstrak daun sirsak ke daun tanaman cabai yang telah diberi label tersebut, dengan ketentuan 0\% (P1), 2\% (P2), 4\% (P3), 6\% (P4), 8\% (P5), 10\% (P6). Masing-masing tiga kali semprotan. Mendiamkan selama 5 hari untuk melihat reaksi yang terjadi. Menghitung mortalitas harian kutu daun persik pada setiap tanaman cabai. Mendata hasil yang didapatkan dalam tabel data kematian hama kutu daun akibat pemberian perlakuan dalam ulangan pada hari pertama sampai hari ke-5 pada tabel pengamatan.

\section{HASIL DAN PEMBAHASAN}

\section{Hasil}

Parameter amatan yang dilakukan pada penelitian ini adalah menghitung jumlah awal kutu daun yang hidup sebelum dilakukan penyemprotan ekstrak daun sirsak dan menghitung jumlah mortalitas dan hilang kutu daun pada setiap perlakuan setelah dilakukan penyemprotan dengan ekstrak daun sirsak selama 5 (lima) hari. Berikut tabel hasil pengamatan.

110 BIOTA: Jurnal Tadris IPA Biologi FITK IAIN Mataram 
Tabel 1

Data hasil pengamatan awal sebelum penyemprotan

\begin{tabular}{|c|c|c|c|c|c|c|c|}
\hline \multirow{2}{*}{ Sampel daun } & \multicolumn{6}{|c|}{ Jumlah awal kutu daun } & \multirow{2}{*}{$\begin{array}{c}\text { Total } \\
\text { (Jumlah } \\
\text { awal) }\end{array}$} \\
\hline & $\mathrm{P} 1$ & P2 & P3 & P4 & P5 & P6 & \\
\hline 1 & 9 & 7 & 11 & 7 & 11 & 10 & 55 \\
\hline 2 & 11 & 7 & 9 & 7 & 15 & 10 & 59 \\
\hline 3 & 12 & 7 & 8 & 5 & 9 & 5 & 46 \\
\hline 4 & 10 & 10 & 6 & 5 & 13 & 5 & 49 \\
\hline 5 & 8 & 5 & 5 & 17 & 5 & 5 & 45 \\
\hline Total & 50 & 36 & 39 & 41 & 53 & 35 & 254 \\
\hline
\end{tabular}

Tabel 2

Data mortalitas kutu Daun Persik Selama 5 hari

\begin{tabular}{|c|c|c|c|c|c|c|c|c|}
\hline \multirow{2}{*}{ Perlakuan } & \multirow[b]{2}{*}{ Ket } & \multicolumn{5}{|c|}{ Pengamatan Hari Ke- } & \multirow{2}{*}{ Total } & \multirow{2}{*}{$\begin{array}{c}\text { Persentase } \\
\text { (\%) }\end{array}$} \\
\hline & & 1 & 2 & 3 & 4 & 5 & & \\
\hline \multirow{3}{*}{$\mathrm{P} 1$} & Hidup & 49 & 46 & 32 & 32 & 32 & 191 & 75 \\
\hline & Hilang & 1 & 6 & 15 & - & - & 22 & 9 \\
\hline & Mati & - & - & - & - & - & - & 0 \\
\hline \multirow{3}{*}{ P2 } & Hidup & 29 & 20 & 18 & 18 & 15 & 100 & 39 \\
\hline & Hilang & 5 & 5 & 2 & - & 2 & 14 & 6 \\
\hline & Mati & 2 & 4 & - & - & - & 6 & 2 \\
\hline \multirow{3}{*}{ P3 } & Hidup & 10 & 5 & 5 & 5 & 4 & 29 & 11 \\
\hline & Hilang & 19 & 3 & - & - & 3 & 25 & 10 \\
\hline & Mati & 9 & 3 & - & - & - & 12 & 5 \\
\hline \multirow{3}{*}{$\mathrm{P} 4$} & Hidup & 11 & 6 & 2 & 1 & 10 & 30 & 12 \\
\hline & Hilang & 20 & 4 & 1 & - & - & 25 & 10 \\
\hline & Mati & 8 & 3 & 3 & 1 & - & 15 & 6 \\
\hline \multirow{3}{*}{ P5 } & Hidup & 3 & - & - & - & - & 3 & 1 \\
\hline & Hilang & 20 & 3 & - & - & - & 23 & 9 \\
\hline & Mati & 26 & 4 & - & - & - & 30 & 12 \\
\hline \multirow{3}{*}{ P6 } & Hidup & 1 & 1 & - & - & - & 2 & 1 \\
\hline & Hilang & 10 & - & - & - & - & 10 & 4 \\
\hline & Mati & 25 & - & - & - & - & 25 & 10 \\
\hline \multicolumn{2}{|c|}{ Total } & 252 & 113 & 78 & 57 & 66 & 566 & \\
\hline
\end{tabular}


Untuk mengetahui potensi anti serangga atau insektisida ekstrak daun sirsak maka data-data yang diperoleh tersebut dihitung persentase aktivitas anti serangganya dengan persamaan

$$
Q \%=\frac{M}{N} \times 100 \%
$$

\section{Keterangan:}

$\mathrm{Q} \%=$ Persentase potensi (aktivitas) insektisida ekstrak daun sirsak

$\mathrm{M}$ = Jumlah sampel kutu yang mati dan hilang

$\mathrm{N}$ = Jumlah awal kutu daun persik (Myzus persicae, Sulz)

Untuk melihat lebih jelas kekuatan atau aktivitas anti serangga berdasarkan persentase hilang dan kematian kutu daun pada setiap perlakuan, maka dibuatkan kategori tingkat aktivitasnya. Kategori tingkat aktivitas atau kekuatan insektisida yang ada dalam ekstrak daun sirsak sebagai berikut:

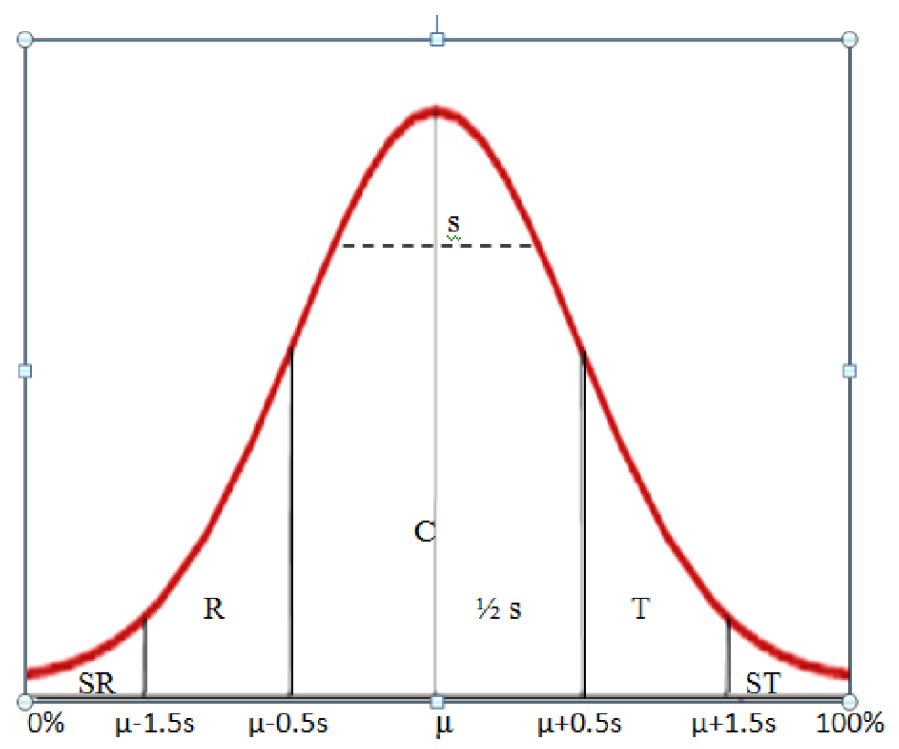

Gambar 1

Kurva Normal

112 BIOTA: Jurnal Tadris IPA Biologi FITK IAIN Mataram 
Keterangan :

$\begin{array}{llrl}\mu & : \text { Rerata (Mean) } & \text { SR } & \text { : Sangat Rendah } \\ \mathrm{S} & : \text { Standar Baku } & \mathrm{R} & \text { : Rendah } \\ \mu-1,5 & : \text { Luas Rata-rata (Mean) Ke Kiri } & \mathrm{C} & : \text { Cukup } \\ \mu+1,5 & : \text { Luas Rata-rata (Mean) Ke Kanan T } & : \text { Tinggi } \\ & & \text { ST } & \text { : Sangat Tinggi }\end{array}$

Rumus penentuan kategori tingkat potensi sebagai berikut:

$$
\begin{aligned}
& S=\frac{100-0}{6}=16,7 \\
& 0 \leq x \leq 50-1,5(16,7)=25 \% \text { (Sangat Rendah) } \\
& 25<x \leq 50-0,5(16,7)=41,7 \% \text { (Rendah) } \\
& 41,5<x<50+0,5(16,7)=58,4 \% \text { (Cukup) } \\
& 58,4<x \geq 50+1,5(16,7)=75 \% \text { (Tinggi) } \\
& 75 \%<x \leq 100 \% \text { (Sangat Tinggi) }
\end{aligned}
$$

Prosentase aktivitas anti serangga dikonversi ke data kategori, diperoleh hasil seperti pada tebel 3 di bawah ini:

Tabel 3

Hasil Persentase Kekuatan Aktivitas Anti Serangga Setelah Lima Hari

\begin{tabular}{|c|c|c|}
\hline Perlakuan & Persentase (\%) & Kategori tingkat potensi \\
\hline P1 & $44 \%$ & Cukup \\
\hline P2 & $55,6 \%$ & Cukup \\
\hline P3 & $94,9 \%$ & Sangat tinggi \\
\hline P4 & $97,6 \%$ & Sangat tinggi \\
\hline P5 & $100 \%$ & Sangat tinggi \\
\hline P6 & $100 \%$ & Sangat tinggi \\
\hline
\end{tabular}




\section{PEMBAHASAN}

Berdasarkan hasil data mortalitas dan hilang kutu daun persik (Myzus persicae, Sulz) menunjukkan semakin tinggi konsentrasi ekstrak daun $A$. muricata maka semakin tinggi pula mortalitas dan hilang dari kutu daun persik tersebut. Semakin tinggi konsentrasi maka senyawa bahan aktif yang terdapat pada ekstrak daun sirsak juga akan semakin tinggi. Pendapat ini diperkuat oleh Harborne (1979) dalam Nursal $d k k$. (1997) dalam Ahmad Daud, dkk. (2011) menyatakan bahwa konsentrasi ekstrak yang lebih tinggi maka pengaruh yang ditimbulkan semakin tinggi pula, di samping itu daya kerja suatu senyawa sangat ditentukan oleh besarnya konsentrasi.

Hal ini terjadi karena adanya kandungan zat isoquanalin alkaloid yang bersifat sebagai antifeedant yang menyebabkan serangga mengalami kematian. Menurut Claus (1962) dalam Padang (2001), tanaman A. muricata mengandung isoquanolin yang termasuk golongan alkaloid. Alkaloid merupakan senyawa yang bersifat basa yang terdapat dalam tanaman tertentu dalam jumlah yang relative kecil dan mempengaruhi aktivitas biologi. Lebih lanjut Panda dan Gurdev (1995), menyatakan bahwa isoquanolin alkaloid merupakan senyawa yang menyebabkan serangga tidak makan, dalam hal ini bersifa antifeedant. Ditambahkan oleh Dadang (1999), bahwa antifeedant merupakan senyawa yang secara substansi tidak memberikan penolakan aktivitas makan tetapi memberikan rasa ketidaksukaan pada serangga.

Dari hasil pengamatan penelitian ini juga dapat dilihat bahwa semua kutu daun pada P5 dan P6 setelah pengamatan hari kedua menunjukkan sampel kutu mati semua. Dapat dikatakan bahwa konsentrasi yang optimum untuk digunakan sebagai insektisida nabati daun sirsak adalah konsentrasi 8\% atau lebih. karena konsentrasi lebih besar dari 8\% membutuhkan waktu lebih singkat.

114 BIOTA: Jurnal Tadris IPA Biologi FITK IAIN Mataram 


\section{KESIMPULAN DAN SARAN}

\section{Simpulan}

Berdasarkan hasil penelitian ini, maka dapat disimpulkan bahwa ekstrak daun sirsak berpotensi sebagai insektisida kutu daun persik (Myzus persicae, Sulz). Kategori tingkat potensi ekstrak daun sirsak sebagai insektisida kutu daun mencapai 100\% (sangat tinggi).

\section{Saran}

Saran-saran yang peneliti sampaikan dari penelitian ini, antara lain:

1. Untuk penelitian selanjutnya, sebaiknya penelitian yang akan dilakukan tidak hanya terbatas pada mortalitas saja, akan tetapi lebih mendalam pada proses gangguan fisiologi atau pertumbuhan hama serangga dan sebaiknya menggunakan konsentrasi ekstrak daun sirsak yang lebih tinggi lagi.

2. Peneliti berharap kepada peneliti selanjutnya agar menguji potensi ekstrak daun sirsak sebagai insektisida alami pada jenis serangga lainnya.

\section{DAFTAR PUSTAKA}

Ahmad Daud, dkk. 2011. Uji Beberapa Konsentrasi Ekstrak Tepung Buah Sirih Hutan (Piper aduncum L) Untuk Mengendalikan Hama Kutu Daun Persik Myzus persicae Sulzer (Homoptera: Aphididae) Pada Tanaman Cabai (Capsicum annum L.) dalam http//jurnal kutu daun.pdf. Diakses pada hari Senin 17 Juni 2013 jam 14.30.

Agus Kardinan. 2002. Pestisida Nabati Ramuan dan Aplikasi. Jakarta: Penebar Swadaya.

Anonim, Perlu Penelitian Lebih Lanjut Mengenai Hama Daun Persik. $\quad$ Redirected from http://www.kalanews.com/teliti/item/268-perlu- 
penelitian-lebih-lanjut-mengenai-hama-daun-persik. Diakses tanggal 19 juni 2013 jam 17.01 WITA.

A. Tenrirawe. 2011. "Seminar Nasional Serelia Pengaruh Ekstrak Daun Sirsak Annona muricata L Terhadap Mortalitas Larva Helicoverpa armigera $H$ Pada Jagung. Balai Penelitian Tanaman Serelia.

Neni Rostini. 2011. 6 Jurus Bertanam Cabai Bebas Hama dan Penyakit. Jakarta: AgroMedia Pustaka.

116 BIOTA: Jurnal Tadris IPA Biologi FITK IAIN Mataram 